\title{
Proteomics Profile of Cronobacter sakazakii and fliF Mutant: Adherence and Invasion to Mouse Neuroblastoma Cells
}

\section{Veronica Esteban-Kenel}

Hospital Infantil de Mexico Federico Gomez

\section{Everardo Curiel-Quesada}

Escuela Nacional de Ciencias Biologicas

Héctor Quezada

Hospital Infantil de Mexico Federico Gomez

\section{Oscar Medina Contreras}

Hospital Infantil de Mexico Federico Gomez

\section{Víctor Luna-Pineda}

Hospital Infantil de Mexico Federico Gomez

\section{Elizabeth Fernández-Rendón}

Escuela Nacional de Ciencias Biologicas

\section{Irma Rosas-Pérez}

Universidad Nacional Autonoma de Mexico

José Arellano-Galindo

Hospital Infantil de Mexico Federico Gomez

\section{Bulmaro Cisneros}

Centro de Investigacion y de Estudios Avanzados del Instituto Politecnico Nacional Juan Xicohtencatl-Cortes ( $\sim$ juanxico@yahoo.com )

Hospital Infantil de Mexico Federico Gomez https://orcid.org/0000-0003-2577-9973

\section{Ariadnna Cruz-Córdova}

Hospital Infantil de Mexico Federico Gomez

\section{Research article}

Keywords: C. sakazakii, proteome, adherence, invasion, flagella

Posted Date: September 27th, 2019

DOl: https://doi.org/10.21203/rs.2.15236/v1 
License: (c) (i) This work is licensed under a Creative Commons Attribution 4.0 International License. Read Full License 


\section{Abstract}

Background: Cronobacter sakazakii is an opportunistic foodborne pathogen associated with necrotizing enterocolitis, bacteraemia, and meningitis in infants. A comparative proteomic study of $\mathrm{C}$. sakazakii ATCC BAA-894 (CS WT) and isogenic mutant of flagella were performed; including the ability of both strains to adhere and invade to N1E-115 cells. Results: To achieve this goal, a non-motile C. sakazakii ATCC BAA-894 fliF ::Tn5 (CS fliF ::Tn5) strain was generated using an EZ-Tn5Tnp Transposome kit. Analysis of differential protein expression showed that $81.49 \%(361 / 443)$ of the proteins were identified in both strains, $8.35 \%$ (37/443) were exclusively expressed in the CS WT strain and $10.16 \%(45 / 443)$ in the CS fliF ::Tn5 strain. The main exclusive proteins from the CS WT strain were classified into the following subcategories: "cell motility" and "signal transduction mechanisms". In contrast, the exclusive proteins from the CS fliF ::Tn5 strain were classified into the following subcategories: "intracellular trafficking, secretion, and vesicular transport", "replication, recombination, and repair", "nucleotide transport and metabolism", "carbohydrate transport and metabolism", "coenzyme transport and metabolism", and "lipid transport and metabolism". Expression of the Cpa protein was shared by both strains but was more abundant in the CS WT strain than in the CS fliF ::Tn5 strain. Significant increases $(p=0.0001)$ in adherence to N1E-115 cells were observed for the non-motile CS fliF ::Tn5 strain, with $31.3 \times 106 \mathrm{CFU} / \mathrm{mL}$, relative to the CS WT strain, with $14.5 \times 106 \mathrm{CFU} / \mathrm{mL}$. Additionally, for infection of N1E-115 cells, the CS WT strain showed a $0.17 \%$ invasion frequency, which was significantly increased $(p=0.01)$ compared to that of the non-motile CS fliF ::Tn5 strain. Conclusion : The proteins involved in motility were mainly identified by proteomic analysis in CS WT strain when compare to CS fliF ::Tn5 strain. Our data showed that flagella are required to promote invasion to N1E-115 cells and absence of flagella significantly increases the adherence to N1E-115 cells when compare to CS WT strain.

\section{Background}

The Cronobactergenus (previously known as Enterobacter sakazakii) is a set of opportunistic foodborne pathogens. Currently, the Cronobactergenus consists of seven species: $C$. sakazakii, $C$. malonaticus, $C$. dublinensis, $C$. muytjensii, $C$. turicensis, $C$. condimenti, and $C$. universalis [1-3]. C. sakazakii is the most commonly isolated and the most studied species in the Cronobactergenus. This opportunistic pathogen exhibits different mechanisms for its adaptation to extreme environments, heat, acid, and osmotic stress [4]. C. sakazakii has been associated with neonatal infections such as bacteraemia, meningitis, and infant necrotizing enterocolitis (NEC) occurring after the consumption of contaminated powdered infant formula [5-7]. Moreover, infections in immunocompromised adults have also been described [4].

The pathogenicity mechanism of $C$. sakazakii is complex and not yet elucidated fully due to the diversity of its virulence properties, which have been identified in the isolates from different regions in the world [8]. Adherence, invasion, and biofilm formation are widely studied processes that allows us to better understand the pathogenesis of these bacteria. Outer membrane protein A (OmpA), OmpX, InvA, and zinc metalloproteases of $C$. sakazakii are proteins that contribute to adherence to and to invasion of human intestinal epithelial cells and brain microvascular endothelial cells. The post-transcriptional global 
regulator Hfq (RNA chaperone) from C. sakazakii is involved in the biogenesis of OMPs and plays an essential role in virulence and in stress adaptation [9-12]. In addition, Cronobacter plasminogen activator (Cpa) is an outer membrane protease that mediates resistance to bactericidal sera and promotes invasion [13].

Flagella of $C$. sakazakii are structural appendages that are composed of several proteins and play several important roles during host colonization [14]. The flagella also participate in motility, adherence, biofilm formation, and the triggering of pro-inflammatory responses through the Toll-like receptor 5 (TLR5) signalling pathway $[14,15]$. However, other studies have revealed that flagellar motility in $C$. sakazakii is not required for biofilm formation [16]. Recently, an autoaggregation in CS29544 was described as an additional biological function for the CS29544 flagellum under environmental conditions that favour the down regulation of motility [17]. The aim of this work was to perform a comparative proteomic study of C. sakazakii ATCC BAA-894 and an isogenic mutant of flagella to determine the effect of differential protein expression on the adherence and invasion to N1E-115 cells.

\section{Results}

Transposon insertion abolished flagella formation

A library of 953 kanamycin-resistant mutants from CS WT strain was obtained using the EZ-TN5 system. From the individual screening of 953 potential mutants, one non-motile kanamycin-resistant strain was identified when a motility test was performed in $0.3 \%$ LB agar plates (Figure $1 \mathrm{~A}$ and B). Flagella absence in the non-motile kanamycin resistant strain and the assembly of several polar flagella around the CS WT bacterium were confirmed by TEM micrographs (Figure 1C and D). The expression of a $\sim 28-\mathrm{kDa}$ FliC protein in the CS WT strain was confirmed by immunoblotting with rabbit anti-FliC antibodies (Figure 1E).

\section{Transposon Tn5 insertion was localized within the fliF gene}

The insertion site of the transposon in the non-motile kanamycin resistant strain was amplified by RATEPCR assays using Tn5-specific primers flanking mosaic end (ME) sequences, a DNA product of approximately 700 bp was sequenced (data not shown).

Bioinformatic analysis of the 700 bp product nucleotide sequence revealed homology with a gene that codes for the hypothetical protein ESA_01260 from CS WT. The predicted amino acid sequence showed $100 \%$ identity with hypothetical protein ESA_01260 from CS WT and 99\% identity with protein FliF from another $C$. sakazakii strains. These data suggested that the insertion site for transposon Tn5 was within the fliF gene from the CS WT strain called C. sakazakii ATCC BAA-894 fliF::Tn5 (CS fliF::Tn5). To corroborate the Tn5 insertion site in the fliF gene a PCR product of 1554 bp to correspond fliF gene in the CS WT strain was obtained and a product of 2775 bp in the CS fliF::Tn5 strain, which contained the insertion of a kanamycin resistance cassette flanking the ME sequence (1221 bp) in the fliF gene (1554 bp) were obtained (Figure 1F). 
fliF interruption led to significant changes in the membrane proteome

Analysis of the purified total membrane proteins from CS WT and CS fliF::Tn 5 strains by SDS-PAGE showed the presence of protein bands among molecular masses of 14.4 and $97 \mathrm{kDa}$ (Figure 2A). Proteomic analyses revealed a total of 443 proteins (Figure 2B and Table S1). Briefly, 361 proteins were shared to both strains, 37 proteins exclusive to the CS WT strain, and 45 proteins to the CS fliF::Tn5 strain (Figure 2B, Table S1). The exclusive proteins identified in the CS WT and CS fliF::Tn5 strains were classified into four groups, each with different subcategories, based on the functional categories assigned by the Cluster of Orthologous Groups (Figure 3 and Table S1).

In the first group, namely, "cellular processes and signalling", 64.86\% (24/37) of the proteins identified were from the CS WT strain and 20\% (9/45) were from the CS fliF::Tn5 strain. Briefly, $45.94 \%$ (17/37) of the exclusive proteins from the CS WT strain were classified in the "cell motility" subcategory and $10.81 \%$ (4/37) were classified within the "signal transduction" subcategory. Additionally, 2.22\% (1/45) of the proteins from the CS fliF::Tn5 strain were classified in the "intracellular trafficking, secretion, and vesicular transport" and "cell wall membrane/envelope biogenesis" subcategories. In the second group, namely, "information storage and processing", 5.4\% (2/37) of the proteins were identified from the CS WT strain, and $15.55 \%(7 / 45)$ of the proteins were identified from the CS fliF::Tn5 strain. In this group, $4.44 \%(2 / 45)$ of the proteins from the CS fliF::Tn5 strain were classified within the "replication, recombination, and repair" subcategory (Figure 3 and Table S1). In the third group, namely, "metabolism", 27.02\% (10/37) of the proteins were from the CS WT strain, and $40 \%(18 / 45)$ of the proteins were from the CS fliF::Tn5 strain. In addition, $17 \%(8 / 45)$ of the exclusive proteins from CS fliF::Tn5 were classified into four subcategories: "lipid transport and metabolism"; "coenzyme transport and metabolism"; "carbohydrate transport and metabolism"; and "nucleotide transport and metabolism"(Figure 4 and Table S1). In the last group, ("poorly characterized"), $24.44 \%$ (11/45) of the proteins were from the CS fliF::Tn5 strain, and $2.70 \%(1 / 37)$ of the proteins were from the CS WT strain (Figure 4 and Table S1). In summary, "cell motility" and "signal transduction mechanisms" were the subcategories that included most of the exclusive proteins from the CS WT strain. The "cell wall membrane biogenesis", "intracellular trafficking, secretion, and vesicular transport", "replication, recombination, and repair", "nucleotide transport and metabolism", "carbohydrate transport and metabolism", "coenzyme transport and metabolism" and "lipid transport and metabolism" subcategories included most of the exclusive proteins from the CS fliF::Tn5 strain (Figure 3 and Table S1).

On the other hand, $6.92 \%$ (25/361) of the proteins showed significant differences in expression (permutation base FDR $£$ 0.05) between the CS fliF::Tn5 and WT strains. According to the protein abundance profile of the CS WT strain, the proteins identified were grouped into the following subcategories: "translation, ribosomal structures and biogenesis" (A7MKJ3, A7MFP6, and A7MQP6); "energy production and conversion" (A7MMX2, A7MQR1, A7MM92, A7MNF6, and A7MMH9), "amino acid transport and metabolism" (A7ML85, A7MQX4, A7MGY5, A7MMT9, and A7MQM1), "inorganic ion transport and metabolism" (A7MEV4), "lipid transport and metabolism" (A7ML71 and A7MHD9), "defense mechanisms" (A7MRK3, A7MRQ5, A7MGV6, A7MMP3, A7MEY6, and A7MHV5) and "general function 
prediction only" (A7MNX3 and A7MI30) (Figure 4 and Table S1). Interestingly, the Cpa (A7MRQ5) protein was identified as more abundant in the CS WT strain compare to CS fliF::Tn5 strain.

Tn5 insertion in the fliF gene enhanced bacterial adherence to N1E-115 cells

The insertional mutation generated in the fliF gene of the CS WT strain allowed us to investigate changes in bacterial adhesion as a function of the loss of flagella. A quantitative analysis of adherence assays using neuronal cells derived from N1E-115 cells showed that the CS WT strain showed an adherence value of $14.5 \times 10^{6} \mathrm{CFU} / \mathrm{mL}$ and the non-motile CS fiF::Tn5 strain an adherence value of $31.3 \times 10^{6}$ $\mathrm{CFU} / \mathrm{mL}$. Similarly, our data revealed a 2.1-fold, significant increase in the adherence levels of the CS fliF::Tn5 strain compared to the adherence levels of the CS WT strain ( $p=0.0001)$ (Figure 5).

Tn5 insertion into the fliF gene decreased bacterial invasion of N1E-115 cells

Invasion assays to N1E-115 cells were performed to explore other virulence-related function of flagella of the CS WT strain. A frequency invasion of $0.17 \%$ was observed for the CS WT strain and $0.001 \%$ with $p=0.01$ for the CS fliF::Tn5 strain (Figure 5).

\section{Discussion}

Chemotaxis and motility by flagella are pathogenic attributes that contribute to biofilm formation, adherence, and invasion in several pathogens; in addition, flagella stimulate the secretion of effector molecules and modulation of the immune system [18-20]. Flagellar motility plays an important role in the pathogenesis of Helicobacter pylori, Pseudomonas aeruginosa, Vibrio cholerae, Salmonella species, and E. coli $[18,21-22]$. The main advantage of bacterial flagella is the ability to direct bacterial movement to a specific colonization site in the host [23].

In this study, 953 clones were obtained by transposition-mediated random mutagenesis, and a single nonmotile clone was identified, whose insertion site was mapped within the fliF gene. Several studies, have shown that random mutagenesis by transposition (EZ-Tn5 $5^{\mathrm{TM}}<\mathrm{Kan}-2>\operatorname{Tnp}$ Transposome ${ }^{\mathrm{TM}}$ ) is an efficient system to generate mutants, allowing the easy identification of their phenotype and mapping [24-27]. This mutation system has shown a high efficiency ratio in other bacteria, such as E. coli $10^{5}>$ Salmonella enterica serovar Typhimurium $10^{4}>$ Proteus vulgaris $10^{3}>$ Pseudomonas spp. $10^{2}$ [28].

The flagella consist of a moving rotor and stationary stator. The rotor includes a cytoplasmic $\mathrm{C}$ ring (FliG, FliM, and FliN proteins) bound to the membrane MS ring (FliF protein), the periplasmic rod, and external hook. These three structures component bound assemble the basal body with a long external helical filament. In the inner membrane, the stationary elements include to the MotA/MotB protein complexes, or stators, which conduct protons to power motor rotation. MotA interacts with FliG positioned at the $\mathrm{C}$ ring top [29]. The FliF protein forms a two-ring-shaped structure called the MS ring, which is one of the initial steps of flagellar assembly. During this process, the C-ring and ATPase are recruited in the cytosol for the assembly of a secretion complex that contains a highly organized central pore that facilitates export of 
the hook protein and other flagellar components to the extracellular space. In addition, several highly organized proteins make up the type-three secretion system, some of which also participate as accessory molecules that control the assembly of the flagellar filament [30]. The MS ring consists of 26 FliF protein repetitions and therefore, a deletion in the fliF gene affects the flagellar assembly and bacterial motility as reported for Salmonella typhimurium, Caulobacter crescentus, Vibrio alginolyticus, and Listeria monocytogenes [29, 31-34].

To determine what types of proteins were expressed, a proteomic analysis of total membrane proteins extracted from CS fliF::Tn5 and CS WT strains was performed. Several specific proteins of the CS fliF::Tn5 strain were not identified in the CS WT strain, and these proteins are of unknown function in the pathogenesis of other bacteria. In addition, extracellular structures involved in polysaccharide and extracellular polysaccharide process were identified exclusively in this mutant. The production of an extracellular polysaccharide matrix and cellulose promote biofilm formation and bacterial aggregation [35-36]. The polysaccharide can also provide diverse benefits to the bacteria within the biofilm, including adhesion to biotic surfaces, environmental protection, and structural integrity [37]. The relevance of this extracellular matrix is fundamental to the successful adaptation of bacteria to a specific host [37]. According to these data, the extracellular structures identified in the mutant strain by proteomic analysis might contribute to biotic or abiotic adherence. Protein A7MMS1 (ESA_01908) identified in the mutant strain is homologous to the putative virulence factor SrfB of Salmonella typhimurium and is one of the proteins activated by the global signal transduction/regulatory system SsrA/B. The activated genes of pathogenicity island-2 and at least ten additional genes (e.g., the srfB gene) are involved in bacterial virulence [38]. Despite observing high levels of adhesion of the mutant strain, we did not find a significant increase in its invasion capacity; however, it is necessary to carry out further studies to determine if other virulence proteins were attenuated by the mutation of the fliF gene affecting the invasion process.

On other hand, CS WT proteins have been mainly associated with flagellum-dependent motility, chemotaxis, and proteins related to the signal transduction mechanism (methyl-accepting chemotaxis protein, CheY-like receiver, and CheZ). Recently, a comparative transcriptomic analysis showed equal expression levels of seven flagellar genes ( $f l g B, f l g L, f l i T, f i D$, flgN, fliR, and $f l g K$ ) between two $C$. sakazakii strains (virulent G362 and attenuated L3101 strains). In contrast, other studies described an upregulation of chemotaxis proteins, outer membrane proteins, lipoproteins, and regulation factors in the $C$. sakazakii virulent G362 strain. Interestingly, in the C. sakazakii-attenuated L3101 strain, upregulation of fliC was observed [39].

Our comparative proteomic analysis data showed that the CS WT and CS fliF::Tn5 strains shared 361 proteins, and 25 of them were described as the most abundant. From the 25 proteins identified, 16 proteins were associated with different biological processes described in the CS WT strain, including identifying $\mathrm{Cpa}$ (the proteolysis outer membrane peptidase omptin) as the most abundant protein compared to $C$. sakazakii ATCC BAA-894 fliF::Tn5. The Cpa protein has been considered an important virulence factor involved in serum resistance as well as in the spread and invasion of $C$. sakazakii [13]. The identification of the Cpa protein in our study is a relevant finding that could help to explain the 
invasion frequency observed in the CS WT strain when infecting HT-29 cells (data not shown) and N1E115 cells. In addition, the seven proteins associated with "stress response", "ion transport", and "lipopolysaccharide production" were identified in the CS fliF::Tn5 strain and are related to the adhesion process on biotic and abiotic surfaces.

The protein A7MRA4 (ESA_pESA2p06588) identified in this study (data not shown) has been associated with the type IV secretory pathway and is homologous to the type IV secretory system VirB11. The type IV secretion system is used to translocate substrates of DNA and protein to other cells through contactdependent mechanisms to other cells. The VirB11 protein is an ATPase, and VirB6, VirB4, and VirB8, make up the inner membrane complex. The type IV secretion pathway is required for delivery of T-DNA and effector proteins during plant infection by Agrobacterium tumefaciens $[40,41]$. The type IV secretion system and putative factor SrfB need to be studied further to better understand the pathogenesis of CS WT.

Several studies have shown adherence to epithelial cells as the first step in bacterial pathogenesis in bacterial pathogens [42]. C. sakazakii also produces virulence factors that contribute to adherence to HEp-2, CaCo-2, human brain microvascular endothelial cells (HBMECs), and IEC-6 cells. The adherence efficiency of $C$. sakazakii is dependent on the cell line [9, 43-45].

Our data showed that the lack of flagella in the CS fliF::Tn5 strain increase the adherence levels to N1E115 cells relative to the CS WT strain. In contrast, other authors have described that the lack of flagella (deletion of the $f l g J$ gene) in the $C$. sakazakii ES5 strain negatively affects its ability to adhere to Caco-2 intestinal cells [14]. The flagellum filament ( $>10 \mathrm{~mm}$ of length) of $S$. typhimurium is responsible for motility and adherence, including the flagellar cap protein FliD, which is involved in the adherence process $[20,46]$. In other pathogens, the deletion of genes coding for the structural proteins of the bacterial flagella may lead to a significant loss in the ability to colonize to the host [47-49]. In agreement with our results, compared with the CS WT strain, mutants of the major flagellar structural subunit FliC and FliD proteins from Clostridium difficile contribute adherence increases to Caco-2 cells. An in vivo model of hamster infection showed mutant strains were more virulent than wild-type strains [50]. These data suggest that flagellar absence or motility repression also might enhance virulence as an adaptive strategy in the pathogenicity of $C$. difficile [50].

On the other hand, the invasion frequencies obtained from the CS fliF::Tn5 strain in N1E-115 cells showed non-significant values, contrary to the adherence values. Interestingly, the CS WT strain displayed higher adherence and invasion frequencies for infection of N1E-115 cells. Additionally, invasion frequency of $0.7 \%$ for Cronobacter species in HBMEC, $0.03 \%$ in CECs (circulating endothelial cells, $0.04 \%$, in IECs (intestinal epithelial cells), $0.2 \%$ in $\mathrm{CHO}$ (Chinese hamster ovary) cells, and $0.3 \%$ in HUVECs (primary human umbilical vein endothelial cells) have been described [51]. In summary, the invasion frequency is dependent on the bacterial strain and the cell line [44,51,52]. Flagellar proteins expressed only in the highly invasive $C$. malonaticus strains maintain a strong correlation with their motility ability and significantly promote bacterial invasion [53]. Interestingly, a significant increase $(p=0.0004)$ was observed 
in CS WT strain adherence to N1E-115 cells. Our results suggest that N1E-115 neuroblastoma cells are highly permissive to infection by the CS WT strain, which may be mediated by specific receptors recognized by the flagella or other outer membrane proteins.

In Salmonella and Bacillus subtilis, a fliF gene mutation represses the flagellin production and only is transcribed after the full assembly of the basal body. In contrast, in Bacillus thuringiensis, inactivation of the gene flhA encoding a protein of the flagellar type III export apparatus, induce the accumulation of intracellular flagellin and the flaA expression. In Listeria monocytogenes, the fla $A$ gene is expressed but flagellin is not detected in fliF mutants, contrary to $B$. subtilis and $B$. thuringiensis. Our results suggesting that the lack of FliF prevents flagellin export, and likely the non-exported product is rapidly degraded in the bacterial cytoplasm of $C$. sakazakii [29].

\section{Conclusions}

Proteome analyzed showed a major number of motility cells proteins in CS WT and an increases in the number of proteins associated to metabolism in CS fliF::Tn5, our data suggest that flagella are required to promote invasion into N1E-115 cells but not the adherence process.

\section{Methods}

Bacterial strains and culture conditions

The bacterial strains used in this study are listed in Table 1. Bacteria were grown in Luria Bertani (LB) broth (DIBICO; CDMX, México) overnight at $37^{\circ} \mathrm{C}$, under aerobic conditions, and constant shaking for the different assays. Routinely, LB agar was used for bacterial isolation and when needed, ampicillin (SigmaAldrich; MI, USA), and/or kanamycin (Amresco; OH, USA) were used at $100 \mathrm{mg} / \mathrm{mL}$ and $50 \mathrm{mg} / \mathrm{mL}$, respectively.

Construction of the transposon mutant library

Transposon libraries were constructed using an EZ-Tn5<KAN-2>Tnp Transposome kit (Epicentre; WI, USA). Briefly, C. sakazakii ATCC BAA-894 (CS WT) was grown in LB broth at $37^{\circ} \mathrm{C}$ until reaching middle-log phase and then was diluted 1:100 in this medium to obtain an optical density of 0.6 at $600 \mathrm{~nm}$ $\left(\mathrm{OD}_{600 \mathrm{~nm}}\right)$. The bacteria were harvested by centrifugation, washed three times with MilliQ ${ }^{\mathrm{a}}$ ultrapure water, and resuspended in $100 \mathrm{~mL}$ of ice-cold $10 \%$ glycerol in MilliQ ${ }^{a}$ ultrapure water. Competent cells $(100 \mathrm{~mL})$ were electroporated with $1 \mu \mathrm{L}$ of EZ-Tn5 ${ }^{\mathrm{TM}}<\mathrm{KAN}-2>\mathrm{Tnp}$ Transposome $^{\mathrm{TM}}$ at $1800 \mathrm{~V} / 5 \mathrm{msec}$ using an ECM 399 electroporation system (BTX Harvard apparatus; MA, USA). The cells were recovered in $1 \mathrm{~mL}$ of SOC medium (Super Optimal Broth) with $20 \mathrm{mM}$ glucose and then incubated at $37^{\circ} \mathrm{C}$ with shaking $\left(200 \mathrm{rev} \mathrm{min}^{-1}\right.$ ) for $4 \mathrm{~h}$. The bacterial culture was diluted 1:100 in SOC medium, and a $100 \mu \mathrm{L}$ aliquot was spread onto LB agar plates with $50 \mathrm{mg} / \mathrm{mL}$ kanamycin and incubated overnight at $37^{\circ} \mathrm{C}$. 
Selected kanamycin-resistant strains that were considered non-motile and stored in LB broth with $7.5 \%$ glycerol including $50 \mathrm{mg} / \mathrm{mL}$ kanamycin.

Screening of non-motile strains by motility assays

The non-motility of kanamycin-resistant strains generated by transposon mutagenesis was confirmed when one colony was spotted into the center of each well in 48-well microplates with $0.3 \%$ LB agar supplemented with $50 \mu \mathrm{g} / \mathrm{mL}$ kanamycin (Corning Life Sciences; NY, USA). The microplates were incubated overnight at $37^{\circ} \mathrm{C}$, and the absence of turbidity absence was a parameter to confirm the motility loss. Non-motile kanamycin-resistant strains were selected and used for the further assays included in this study.

Visualization of $C$. sakazakii strains by electron microscopy

The presence or absence of flagella around bacterial cells was visualized by transmission electron microscopy (TEM). CS WT and the non-motile kanamycin-resistant mutant strains were grown overnight in LB broth at $37^{\circ} \mathrm{C}$ and one drop of the bacterial culture was placed on a 200 mesh formvar-carboncoated grid (Electron Microscopy Sciences, London) for 5 min [15]. Excess liquid was wiped off, and the grid with bacteria was negatively stained with $1 \%$ sodium phosphotungstic acid $(\mathrm{pH} 7.2)(\mathrm{MP}$ Biomedicals; $\mathrm{OH}, \mathrm{USA}$ ) for 5 min. The samples were washed three times with distilled water and visualized under a JEM-1010 microscope (JEOL; Tokyo, Japan).

Immunoblotting assays

Sodium dodecyl sulfate-polyacrylamide gel electrophoresis (SDSPAGE) was performed as described by Laemmli [54]. Bacterial suspensions were adjusted to an absorbance of 1.0 at $\mathrm{OD}_{600}$; the pellet was separated by spinning at 4,000 $\mathrm{xg}$ for 5 min and then mixed with $100 \mu \mathrm{L}$ of SDS-PAGE sample buffer (4\% w/v SDS, $10 \%$ v/v $\beta$-mercaptoethanol, $0.125 \mathrm{mM}$ Tris-HCl pH $6.8,20 \%$ v/v glycerol, and $0.0025 \% \mathrm{w} / \mathrm{v}$ bromophenol blue) $1 \mathrm{X}$ and heated at $90^{\circ} \mathrm{C}$ for $5 \mathrm{~min}$ prior to electrophoresis. Twenty-five-microliter aliquots from whole-cell extracts (equal cell numbers) were loaded for $12 \%$ SDS-PAGE and run at $100 \mathrm{~V}$ for $2 \mathrm{~h}$ at room temperature. The proteins were immobilized onto a nitrocellulose membrane and incubated using blocking buffer [TBS containing $0.1 \%(\mathrm{v} / \mathrm{v})$ Tween 20 and $5 \%$ skim milk], reacted for $1 \mathrm{~h}$ with rabbit anti-FliC antibodies at a dilution of 1:1,500, washed 3 times with TBS-Tween $0.1 \%$, and then incubated for $1 \mathrm{~h}$ with alkaline phosphatase-conjugated goat anti-rabbit antibody at a 1:20,000 dilution (Sigma Aldrich; MO, USA). The membrane was washed and exposed to 5-bromo-4-chloro-3-indolylphosphate/nitro blue tetrazolium (BCIP/NBT) (Merck Millipore; MA, USA).

Identification of transposon insertion sites

Random amplification of transposon ends (RATE)-PCR was performed using primer Tn5PCRF (5'GCTGAGTTGAAGGATCAGATC-3') or Tn5PCRR (5'-CGAGCAAGACGTTCCCGTTG-3'). The amplification was carried out with the following thermal cycles: 1 min at $94^{\circ} \mathrm{C} ; 20$ cycles of $94^{\circ} \mathrm{C}$ for $30 \mathrm{~s}, 50^{\circ} \mathrm{C}$ for $30 \mathrm{~s}$, 
$72^{\circ} \mathrm{C}$ for $3 \mathrm{~min} ; 30$ cycles of $94^{\circ} \mathrm{C}$ for $30 \mathrm{~s}, 30^{\circ} \mathrm{C}$ for $30 \mathrm{~s}, 72^{\circ} \mathrm{C}$ for $2 \mathrm{~min} ; 30$ cycles of $94^{\circ} \mathrm{C}$ for $30 \mathrm{~s}, 50^{\circ} \mathrm{C}$ for $30 \mathrm{~s}, 72^{\circ} \mathrm{C}$ for $2 \mathrm{~min}$; and $72^{\circ} \mathrm{C}$ for $7 \mathrm{~min}$, as previously described (Álvarez-Ordóñez et al., 2014b). The reaction was performed using Platinum ${ }^{\circledR}$ Taq DNA Polymerase High Fidelity (Invitrogen; CA, USA). The PCR products were purified with Zymoclean Gel DNA Recovery (Zymo Research; CA, USA), cloned into the pJET1.2/blunt vector (Thermo Scientific; CA, USA) and transformed into Escherichia coli BL21. DNA sequencing was carried out with BigDye® terminator v1.1 cycle sequencing (Applied Biosystems; California, USA) using $100 \mathrm{ng}$ of reverse primer and $500 \mathrm{ng}$ of purified DNA template (Table 2). The products were precipitated (EDTA $125 \mathrm{mM}$ and absolute ethanol) and sequenced using an ABI Prism 377 sequencer (Applied Biosystems; California, USA). The data generated from DNA sequencing were analyzed and compared with a reference nucleotide sequence database in NCBI for bacteria using BLAST and aligned via multiple sequence alignment with hierarchical clustering [55].

\section{Extraction and processing of proteins}

Non-motile (CS fliF::Tn5) and C. sakazakii WT (CS WT) strains were grown in N1E-115 preconditioned media overnight at $37^{\circ} \mathrm{C}$ with shaking and total membrane proteins were obtained using sucrose gradient centrifugation, as described by Thein et al, [56]. The samples were treated with $50 \mu \mathrm{g}$ of total proteins; dissolved in 1\% SDS (Sigma-Aldrich, MI, USA), $50 \mathrm{mM} \mathrm{NH}_{4} \mathrm{HCO}_{3}$ (Sigma-Aldrich, MI, USA), and $10 \mathrm{mM}$ dithiothreitol (DTT; Sigma-Aldrich, MI, USA); and incubated at $40^{\circ} \mathrm{C}$ for $30 \mathrm{~min}$. Subsequently, the proteins were alkylated with $20 \mathrm{mM}$ iodoacetamide (Sigma-Aldrich, MI, USA) and $30 \mathrm{mM}$ Tris-HCl pH 8.6 (Promega, WI, USA) for $30 \mathrm{~min}$ at room temperature in the dark. Proteins were precipitated with 9 volumes of ethanol (Sigma-Aldrich, MI, USA) at $-20^{\circ} \mathrm{C}$ overnight and centrifuged at $20,000 \times \mathrm{g}$ for $10 \mathrm{~min}$ at $4^{\circ} \mathrm{C}$; the supernatant was discarded, and the pellet was washed three times with $90 \%$ cold ethanol and then dried. The pellets were solubilized in $50 \mathrm{mM} \mathrm{NH}_{4} \mathrm{HCO}_{3}$ and $50 \mathrm{mM}$ guanidine hydrochloride (Sigma-Aldrich, Ml USA) and then digested overnight with $1 \mu \mathrm{g}$ of mass spectrometry grade trypsin (Promega, WI, USA) at $37^{\circ} \mathrm{C}$. Peptides were desalted with Sep-Pak tC18 cartridges (Waters, MA, USA), dried in a SpeedVac concentrator (Thermo Scientific, MA, USA), and stored at $-80^{\circ} \mathrm{C}$. The samples were reconstituted in $50 \mu \mathrm{L}$ of $0.1 \%$ formic acid, centrifuged at $20,000 \times \mathrm{g}$ at $4^{\circ} \mathrm{C}$ for 5 min and injected on a C18 Nano HPLC column for peptide separation.

Nanoflow liquid ehromatography (Nano LC)-quadrupole time-of fight tandem mass

Spectrometry (QTOF) analysis

The peptide solutions $(5 \mu \mathrm{L})$ were loaded into a Thermo UltiMate 3000 HPLC system (Thermo Scientific,

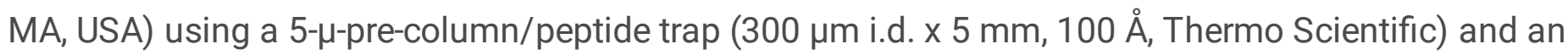
Acclaim PepMap RSLC C18 ( $3 \mu \mathrm{m}, 100 \AA, 75 \mu \mathrm{m}$ i.d. $\times 15 \mathrm{~cm}$, nanoViper) separation column.

Chromatographic runs were performed at a constant flow of $250 \mathrm{~nL} / \mathrm{min}$ of a mixture of $0.1 \%(\mathrm{v} / \mathrm{v})$ formic acid/water (Buffer A, from a Milli-Q system; MA, USA) and $0.1 \%(\mathrm{v} / \mathrm{v})$ formic acid/acetonitrile (Buffer B, HPLC grade from Sigma-Aldrich; MA, USA) in a linear gradient of $200 \mathrm{~min}$ from $1-30 \% \mathrm{~B}$. The gradient was increased to $90 \%$ B at $210 \mathrm{~min}$ and held there for $8 \mathrm{~min}$, after which the percentage of B was 
returned to $1 \%$ for column re-equilibration. Electrospray ionization of the eluted peptides was performed with a CaptiveSpray source (Bruker; MA, USA) assisted by a flow of nitrogen boiled on acetonitrile $(0.2$ bar), and the mass spectra were acquired with a quadrupole time-of-flight mass spectrometer (Impact II, Bruker). Positive ions were analyzed over an $\mathrm{m} / \mathrm{z}$ range of 300-2200. Prior to every six injections, calibration was performed with ESI-TOF Tuning Mix (Sigma-Aldrich, MI, USA). MS/MS fragmentation was performed for ions with a signal higher than 5000 counts, applying a cycle time of $3 \mathrm{~s}$ and excluding +1 charged ions. Exclusion was active after one spectrum for $2 \mathrm{~min}$, unless the precursor intensity was more than three times higher than that in the previous scan. The collision energy depended on the precursor ion charge and mass (e.g., at $700 \mathrm{~m} / \mathrm{z}, 33 \mathrm{eV}$ and $27 \mathrm{eV}$ were used for 2+ and 3+ ions, respectively, whereas at $1100 \mathrm{~m} / \mathrm{z}, 65 \mathrm{eV}$ and $55 \mathrm{eV}$ were used for $2+$ and $3+$ ions).

Database search and analysis of proteomic data

Protein identification was performed by processing the raw files with the Datanalysis-o-TOF-Default script from the Bruker Compass Datanalysis software (version 4.2 SR2, Bruker; MA, USA). The resultant .xml files were then analyzed in the ProteinScape software (version 3.1, Bruker; MA, USA) using Mascot 2.4.1 (Matrix Science; London, UK) with the following parameters: trypsin as the digestion enzyme with two miscleavages allowed, carbamidomethyl Cys as a fixed modification and oxidation on Met as variable modification. Monoisotopic peptide masses were searched with 7-ppm peptide mass tolerance and 0.05 Da fragment mass tolerance. The false discovery rate (FDR) was set to $1 \%$, and peptide decoy and percolator options were active. The $C$. sakazakii strain ATCC BAA-894 UniProt reviewed and unreviewed databases were used. Proteins with Mascot scores > 13 and at least two peptides per protein were considered positive hits. Only proteins common to at least two analytical replicates were considered successful identifications.

A comparison of the relative protein abundance (heat map) was made using the Label Free Quantification (LFQ) tool of MaxQuant software (version 1.5.8.3) and the Andromeda search engine (version 1.5.6.0) loaded with the $C$. sakazakii ATCC BAA-894 UniProt databases mentioned above. The search parameters were as follows: carbamidomethyl cysteine as a fixed modification, $\mathrm{N}$-terminal acetylation and methionine oxidation as variable modifications, two missed cleavages of the protease trypsin allowed, Bruker Q-TOF as the analyzer, peptide mass tolerance of $0.07 \mathrm{Da}, \mathrm{MS} / \mathrm{MS}$ mass tolerance of $40 \mathrm{ppm}$, and an FDR of $1 \%$ at the protein level. Perseus software (version 1.5.8.4) was used to combine the MaxQuant results from three analytical replicates of each sample. Only those proteins identified in the three analytical replicates of both strains were considered for calculations in the fold change. A protein was considered differentially expressed if the fold change was higher than 1.5 , if the difference was statistically significant ( $F D R=0.05$, permutation based-FDR, $Q<0.015$, Student's t-test) and if the protein was identified based on a minimum of one peptide. The percentage of overlap at the protein level in the triplicate HPLC runs was higher than $93 \%$, and that of the two biological replicates was $80 \%$. To assess the reproducibility of the LFQ analysis, the scatter plot and the correlation coefficient calculation were performed based on the LFQ intensities. The average Pearson correlation coefficient of the technical replicates was of $0.91 \pm 0.03$. 
Adherence assays

Mouse neuroblastoma (N1E-115 ATCCÒCRL-2263; Manassas, USA) cells were cultured in Dulbecco's Modified Eagle Medium (DMEM) high glucose $4.5 \mathrm{~g} / \mathrm{L}$ from GIBCO (Thermo Scientific; MA, USA) and supplemented with $10 \%$ fetal bovine serum (FBS) from GIBCO (Thermo Scientific; MA, USA). N1E-115 cell differentiation was performed after induction with DMEM high glucose medium supplemented with $2 \%$ FBS and 1.25\% dimethyl sulfoxide (DMSO) (Sigma-Aldrich; MI, USA) for 5 days. Briefly, cell monolayers at $70-80 \%$ confluence in 24-well plates containing $1 \mathrm{~mL}$ of DMEM were infected at an MOI of 100:1 and incubated at $37^{\circ} \mathrm{C}$ and $5 \% \mathrm{CO}_{2}$ for $4 \mathrm{~h}$ according to the method of Cruz et al. [44]. Initially, the non-motile (generated in this study) and WT CS strains were cultured overnight in LB at $37^{\circ} \mathrm{C}$. The non-attached bacteria were removed, and the bacteria attached to the cell monolayers were removed by adding $1 \mathrm{~mL}$ of 0.1\% Triton X-100 (Amresco, OH, USA). The bacterial cells that adhered to N1E-115 monolayers were collected, and serial dilutions were plated onto LB agar plates to determine the number of colony forming units (CFU)/mL. The adherence assays were performed three times in triplicate on different days, and the data are expressed as the mean of the averages.

Invasion assays

To perform invasion assays, N1E-115 cell monolayers were prepared and infected according to the procedure described in the adherence assay section. The infected cells monolayers were washed with $1 \mathrm{X}$ PBS and incubated with DMEM supplemented with $300 \mu \mathrm{g} / \mathrm{mL}$ lysozyme (Sigma-Aldrich, MI, USA) and $100 \mu \mathrm{g} / \mathrm{mL}$ gentamicin (Sigma-Aldrich; MI, USA) for $2 \mathrm{~h}$ at $37^{\circ} \mathrm{C}$ and $5 \% \mathrm{CO}_{2}$. The infected cell

monolayers were washed three times with 1 X PBS, detached with $1 \mathrm{~mL}$ of $0.1 \%$ Triton X-100, and plated onto LB agar plates. The invasion frequency was calculated as the number of surviving bacteria after treatment with gentamycin and lysozyme divided by the total number of bacteria without treatment with these antibiotics [57]. The invasion assays were performed three times in triplicate on different days, and the data are expressed as the means of the averages.

Statistical analysis

Statistical significance $(\mathrm{p}<0.05)$ was determined using Student's t-test for adherence and invasion assays.

\section{Abbreviations}

CS WT: C. sakazakii ATCC BAA-894 and CS fliF::Tn5: C. sakazakii ATCC BAA-894 fliF::Tn5.

\section{Declarations}

Author Contributions 
Designed and conceived the experiments: CCA and XCJ. Performed the experiments: EKV, QH and MCO. Analyzed the data: CCA, XCJ, and CQE. Contributed reagents/materials/analytical tools: CCA, XCJ, CQE, OSA, QH, FRE, RPI, LPV, CB and AGJ. Wrote and reviewed the manuscript: CCA and XCJ. Suggestions for the manuscript: CQE, OSA, RPI, FRE and CB.

\section{Availability of data and materials}

All data generated in this study are included in this article and in supplementary information file.

Ethics statement

This study is part of HIM/2017/135 SSA1455 and was approved by the Research Committee (Dr. Juan Garduño Espinosa), Ethics Committee (Dr. Luis Jasso Gutierrez), and Biosecurity Committee (Dra. Marcela Salazar García) of the Hospital Infantil de México Federico Gómez.

Conflict of Interest

The authors declare that the research was conducted in the absence of any commercial or financial relationships that could be construed as a potential conflict of interest.

Funding

This work was supported by public funds HIM/2014/007, HIM/2015/053 SSA1183, and HIM/2016/026 SSA1222, HIM/2017/135 SSA1455 from Hospital Infantil de México Federico Gómez (HIMFG).

Acknowledgments

Veronica Esteban Kenel has been awarded fellowship 307218 from CONACYT. We thank Posgrado en CienciasQuímico-Biológicas, Escuela Nacional de Ciencias Biológicas, Instituto Politécnico Nacional. Eva Salinas Cortes, Leticia Martínez Romero, Ana Karina Espinosa Mazariego, Gerardo Escalona Venegas, and Vicenta Cazares Domínguez for their technical assistance; Eva Martínez Peñafiel for her contribution to the sequencing analysis; and Rosario Espinoza Mellado for her assistance in TEM.

\section{References}

1. Farmer JJ, Asbury MA, Hickman FW, Brenner DJ. The enterobacteriaceae study group (USA). Int J Syst Bacteriol. 1980;30:569-584.

2. Iversen C, Mullane N, McCardell B, Tall BD, Lehner A, Fanning S, et al. Cronobacter nov., a new genus to accommodate the biogroups of Enterobacter sakazakii, and proposal of Cronobacter sakazakii gen. nov., comb. nov., Cronobacter malonaticus sp. nov., Cronobacter turicensis sp. nov., Cronobacter muytjensii sp. nov., Cronobacter dublinensis sp. nov., Cronobacter genomospecies 1, and of three subspecies, Cronobacter dublinensis subsp. dublinensis subsp. nov., Cronobacter dublinensis subsp. 
lausannensis subsp. nov. and Cronobacter dublinensis subsp. lactaridi subsp. nov. Int. J Syst Evol Microbiol. 2008;58:1442-1447.

3. Joseph S, Cetinkaya E, Drahovska H, Levican A, Figueras MJ, Forsythe SJ. Cronobacter condimenti sp. nov., isolated from spiced meat, and Cronobacter universalis nov., a species designation for Cronobacter sp. genomospecies 1, recovered from a leg infection, water and food ingredients. Int J Syst Evol Microbiol. 2012;62:1277-1283.

4. Holý O, Forsythe S. Cronobacter as emerging causes of healthcare-associated infection. J Hosp Infect. 2014;86:169-177.

5. Biering G, Karlsson S, Clark NC, Jonsdottir KE, Ludvigsson P, Steingrimsson O. Three cases of neonatal meningitis caused by Enterobacter sakazakii in powdered milk. J Clin Microbiol. 1989;27: 2054-2056.

6. Bar-Oz B, Preminger A, Peleg O, Block C, Arad I. Enterobacter sakazakii infection in the newborn. Acta Paediatr. 2001;90:356-358.

7. Hoque A, Ahmed T, Shahidullah M, Hossain A, Mannan A, Noor K, et al. Isolation and molecular identification of Cronobacter from powdered infant formula (PIF) in Bangladesh. Int J Food Microbiol. 2010;142:375-378.

8. Kucerova E, Clifton SW, Xia XQ, Long F, Porwollik S, Fulton L, et al. Genome sequence of Cronobacter sakazakii BAA-894 and comparative genomic hybridization analysis with other cronobacter species. PLoS One. 2010;5;e9556.

9. Mange JP, Stephan R, Borel N, Wild P, Kim K, Pospischil A, et al. Adhesive properties of Enterobacter sakazakii to human epithelial and brain microvascular endothelial cells. BMC Microbiol. 2006;6:58.

10. Nair MKM, Venkitanarayanan K, Silbart LK, Kim KS. Outer membrane protein A (OmpA) of Cronobacter sakazakii binds fibronectin and contributes to invasion of human brain microvascular endothelial cells. Foodborne Pathog. Dis. 2009;6:495-501.

11. Kim K, Kim KP, Choi J, Lim JA, Lee J, Hwang S, et al. Outer membrane proteins A (OmpA) and X (OmpX) are essential for basolateral invasion of Cronobacter sakazakii. Appl Environ Microbiol. 2010;76:5188-5198.

12. Kim S, Hwang H, Kim KP, Yoon H, Kang DH, Ryu, S. Hfq plays important roles in virulence and stress adaptation in Cronobacter sakazakii ATCC 29544. Infect Immun. 2015;83:2089-2098.

13. Franco AA, Kothary MH, Gopinath G, Jarvis KG, Grim CJ, Hu L, et al. Cpa, the outer membrane protease of Cronobacter sakazakii, activates plasminogen and mediates resistance to serum bactericidal activity. Infect Immun. 2011;79:1578-1587.

14. Hartmann I, Carranza P, Lehner A, Stephan R, Eberl L, Riedel K. Genes involved in Cronobacter sakazakii biofilm formation. Appl Environ Microbiol. 2010;76:2251-2261.

15. Cruz-Cordova A, Rocha-Ramirez LM, Ochoa SA, Gonzalez-Pedrajo B, Espinosa N, Eslava C, et al. Flagella from five Cronobacter species induce pro-inflammatory cytokines in macrophage derivatives from human monocytes. PLoS One. 2012;7:e52091. 
16. Ye Y, Gao J, Jiao R, Li H, Wu Q, Zhang J, et al. The membrane proteins involved in virulence of Cronobacter sakazakii virulent G362 and attenuated L3101 isolates. Front Microbiol. 2015;6:1238.

17. Hoeflinger JL, Miller MJ. Cronobacter sakazakii ATCC 29544 autoaggregation requires FliC flagellation, not motility. Front Microbiol. 2017;8:301.

18. Ramos HC, Rumbo M, Sirard JC. Bacterial flagellins: mediators of pathogenicity and host immune responses in mucosa. Trends Microbiol. 2004;12:509-517.

19. Duan Q, Zhou M, Zhu L, Zhu G. Flagella and bacterial pathogenicity. J Basic Microbiol. 2013;53:1-8.

20. Haiko J, Westerlund-Wikström B. The role of the bacterial flagellum in adhesion and virulence. Biology. 2013;2:1242-1267.

21. Josenhans $C$, Suerbaum S. The role of motility as a virulence factor in bacteria. Int $J$ Med Microbiol. 2002;291:605-614.

22. Sampaio SCF, Luiz WB, Vieira MAM, Ferreira RCC, Garcia BG, Sinigaglia-Coimbra R, et al. Flagellar cap protein FliD mediates adherence of atypical enteropathogenic Escherichia coli to enterocyte microvilli. Infect Immun. 2016;84:1112-1122.

23. Baban ST, Kuehne SA, Barketi-Klai A, Cartman ST, Kelly ML, Hardie KR, et al. The role of flagella in Clostridium difficile pathogenesis: comparison between a non-epidemic and an epidemic strain. PLoS One. 2013; 8:e73026.

24. Johler S, Stephan R, Hartmann I, Kuehner KA, Lehner A. Genes involved in yellow pigmentation of Cronobacter sakazakii ES5 and influence of pigmentation on persistence and growth under environmental stress. Appl Environ Microbiol. 2010;76:1053-1061.

25. Schwizer S, Tasara T, Zurfluh K, Stephan R, Lehner A. Identification of genes involved in serum tolerance in the clinical strain Cronobacter sakazakii BMC Microbiol. 2013;13:38.

26. Álvarez-Ordóñez A, Begley M, Clifford T, Deasy T, Collins B, Hill C. Transposon mutagenesis reveals genes involved in osmotic stress and drying in Cronobacter sakazakii. Food Res Int. 2014a; 55:45-54.

27. Alvarez-Ordóñez A, Cummins $C$, Deasy T, Clifford T, Begley M, Hill C. Acid stress management by Cronobacter sakazakii. Int J Food Microbiol. 2014b;178: 21-28.

28. Hoffman LM, Jendrisak J. Use of EZ:TN ${ }^{T M}$ transposomes $^{T M}$ for genetic analysis and direct sequencing of bacterial genomic DNA. Curr Genet. 1999;35:304-377.

29. Bigot A, Pagniez H, Botton E, Frehel C, Dubail I, Jacquet C, et al. Role of FliF and Flil of Listeria monocytogenes in flagellar assembly and pathogenicity. Infect Immun. 2005;73:5530-5539.

30. Minamino T, Imada K, Namba K. Mechanisms of type III protein export for bacterial flagellar assembly. Mol Biosyst. 2008; 4:1105-1115.

31. Kihara M, Minamino T, Yamaguchi S, Macnab RM. Intergenic suppression between the flagellar MS ring protein FliF of Salmonella and FlhA, a membrane component of its export apparatus. J Bacteriol. 2001;183:1655-1662.

32. Thomas D, Morgan DG, DeRosier DJ. Structures of bacterial flagellar motors from two FliF-FliG gene fusion mutants. J Bacteriol. 2001;183:6404-6412. 
33. Grunenfelder B, Gehrig S, Jenal U. Role of the cytoplasmic C terminus of the FliF motor protein in flagellar assembly and rotation. J. Bacteriol. 2003;185:1624-1633.

34. Ogawa R, Abe-Yoshizumi R, Kishi T, Homma M, Kojima S. Interaction of the C-terminal tail of FliF with FliG from the Na+-driven flagellar motor of Vibrio alginolyticus. J Bacteriol. 2015;197: 63-72.

35. Hu L, Grim CJ, Franco AA, Jarvis KG, Sathyamoorthy V, Kothary MH, et al. Analysis of the cellulose synthase operon genes, $b \operatorname{cs} A, b \operatorname{cs} B$, and $b c s C$ in Cronobacter species: prevalence among species and their roles in biofilm formation and cell-cell aggregation. Food Microbiol. 2015;52:97-105.

36. Bao X, Yang L, Chen L, Li B, Li L, Li Y, et al. Analysis on pathogenic and virulent characteristics of the Cronobacter sakazakii strain BAA-894 by whole genome sequencing and its demonstration in basic biology science. Microb Pathog. 2017;109:280-286.

37. Limoli DH, Jones CJ, Wozniak DJ. Bacterial extracellular polysaccharides in biofilm formation and function. Microbiol Spectr. 3. 2015 doi:10.1128/microbiolspec.MB-0011-2014.

38. Worley MJ, Ching KHL, Heffron F. Salmonella SsrB activates a global regulon of horizontally acquired genes. Mol Microbiol. 2002;36:749-761.

39. Ye $\mathrm{Y}$, Zhang $\mathrm{X}$, Zhang $\mathrm{M}$, Ling $\mathrm{N}$, Zeng $\mathrm{H}$, Gao J, et al. Potential factors involved in virulence of Cronobacter sakazakii isolates by comparative transcriptome analysis. J Dairy Sci. 2017;100:88268837

40. Chandran DV, Waksman G. Structural biology of bacterial type IV secretion systems. Annu Rev Biochem. 2015;84:603-629.

41. Christie PJ, Whitaker N, González-Rivera C. Mechanism and structure of the bacterial type IV secretion systems. Biochim Biophys Acta. 2014;1843:1578-1591.

42. Quintero-Villegas MI, Wittke A, Hutkins R. Adherence inhibition of Cronobacter sakazakii to intestinal epithelial cells by lactoferrin. Curr Microbiol. 2014;69:574-579.

43. Townsend SM, Hurrell E, Gonzalez-Gomez I, Lowe J, Frye JG, Forsythe S, et al. Enterobacter sakazakii invades brain capillary endothelial cells, persists in human macrophages influencing cytokine secretion and induces severe brain pathology in the neonatal rat. Microbiology. 2007;153: 35383547.

44. Cruz A, Xicohtencatl-Cortes J, González-Pedrajo B, Bobadilla M, Eslava C, Rosas I. Virulence traits in Cronobacter species isolated from different sources. Can J Microbiol. 2011;57:735-744.

45. Liu Q, Mittal R, Emami CN, Iversen C, Ford HR, Prasadarao NV. Human isolates of Cronobacter sakazakii bind efficiently to intestinal epithelial cells in vitro to induce monolayer permeability and apoptosis. J Surg Res. 2012;176:437-447.

46. Elhadad D, Desai P, Rahav G, McClelland M, Gal-Mor O. Flagellin is required for host cell invasion and normal salmonella pathogenicity island 1 expression by Salmonella enterica serovar paratyphi A. Infect Immun. 2015;83:3355-3368.

47. Richardson K. Roles of motility and flagellar structure in pathogenicity of Vibrio cholerae: analysis of motility mutants in three animal models. Infect Immun. 1991;59:2727-2736. 
48. Eaton KA, Morgan DR, Krakowka S. Motility as a factor in the colonisation of gnotobiotic piglets by Helicobacter pylori. J Med Microbiol. 1992;37:123-127.

49. Yao R, Burr DH, Doig P, Trust TJ, Niu H, Guerry P. Isolation of motile and non-motile insertional mutants of Campylobacter jejuni: the role of motility in adherence and invasion of eukaryotic cells. Mol Microbiol. 1994;14: 883-893.

50. Dingle TC, Mulvey GL, Armstrong GD. Mutagenic analysis of the Clostridium difficile flagellar proteins, FliC and FliD, and their contribution to virulence in hamsters. Infect Immun. 2011;79: 40614067.

51. Singamsetty VK, Wang Y, Shimada H, Prasadarao NV. Outer membrane protein A expression in Enterobacter sakazakii is required to induce microtubule condensation in human brain microvascular endothelial cells for invasion. Microb Pathog. 2008;45:181-191.

52. Schauer K, Lehner A, Dietrich R, Kleinsteuber I, Canals R, Zurfluh K, et al. A Cronobacter turicensis 01 antigen-specific monoclonal antibody inhibits bacterial motility and entry into epithelial cells. Infect Immun. 2015;83:876-887.

53. Aldubyan MA, Almami IS, Benslimane FM, Alsonosi AM, Forsythe SJ. Comparative outer membrane protein analysis of high and low-invasive strains of Cronobacter malonaticus. Front. Microbiol. 2017; 8:2268.

54. Laemmli UK. Cleavage of structural proteins during the assembly of the head of bacteriophage T4. Nature. 1970; 227:680-685.

55. Corpet F. Multiple sequence alignment with hierarchical clustering. Nucleic Acid Res. 1988;16: 1088110890.

56. Thein M, Sauer G, Paramasivam N, Grin I, Linke D. Efficient subfractionation of gram-negative bacteria for proteomics studies. J Proteome Res. 2010;9:6135-6147.

57. Arikawa K, Nishikawa Y. Interleukin-8 induction due to diffusely adherent Escherichia coli possessing Afa/Dr genes depends on flagella and epithelial toll-like receptor 5. Microbiol Immunol 2010; 54:491501.

\section{Tables}

Table 1. Strains used in this study. 
C. sakazakii Wild-type strain, motile, producer of yellow pigment.

ATCC BAA-

894

E. coli BL21 High transformation efficiency, cloning and propagation of plasmid, stable replication. FmcrA $\Delta$ (mrr-hsdRMS-mcrBC) $\varphi 80 l a c Z \Delta M 15$ slacX74 nupG recA1 araD139 $\Delta$ (ara-leu) 7697 alE15 galK16 $\operatorname{rpsL}\left(\mathrm{Str}^{\mathrm{R}}\right)$ endA1 $\lambda^{-}$.

C. sakazakii Non-motile, $\mathrm{Km}^{\mathrm{R}}$, producer of yellow pigment, $\mathrm{fliF}^{2}$.

ATCC BAA-

894 fliF::Tn5

Table 2. Primers used in this study.

\begin{tabular}{ccc}
\hline Primers & Sequences (5’-3’) & References \\
Tn5PCRF & GCTGAGTTGAAGGATCAGATC & Alvarez-Ordóñez et al. (2014b) \\
Tn5PCRR & CGAGCAAGACGTTTCCCGTTG & Alvarez-Ordóñez et al. (2014b) \\
pJET1.2 F & CGACTCACTATAGGGAGAGCGGC & Thermo Scientific \\
pJET1.2 R & AAGAACATCGATTTTCCATGGCAG & Thermo Scientific \\
flif F & TCAGCGCGAGCGGCTTGCCGTTGCCC & This study \\
flif R & CGGAGGGCGGGGTCTCGACAGC & This study \\
\hline
\end{tabular}

\section{Figures}


A
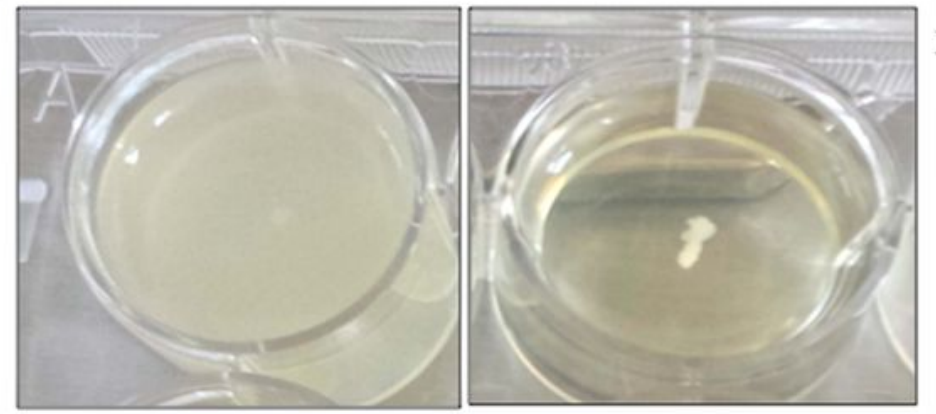

C
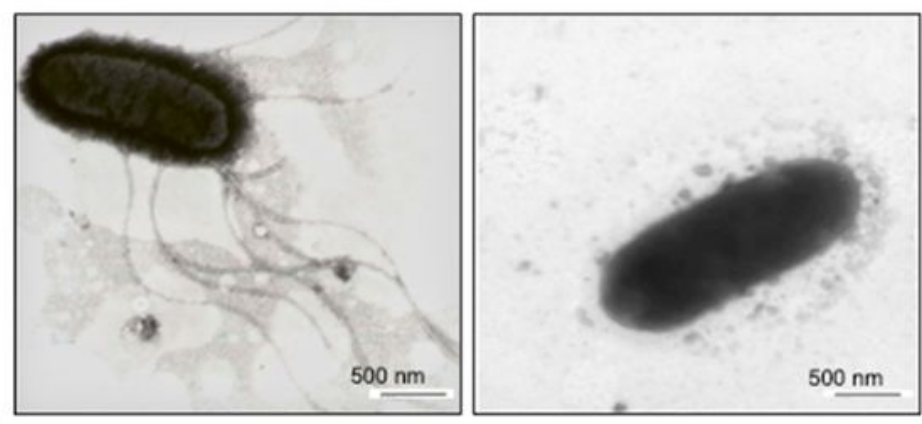

D
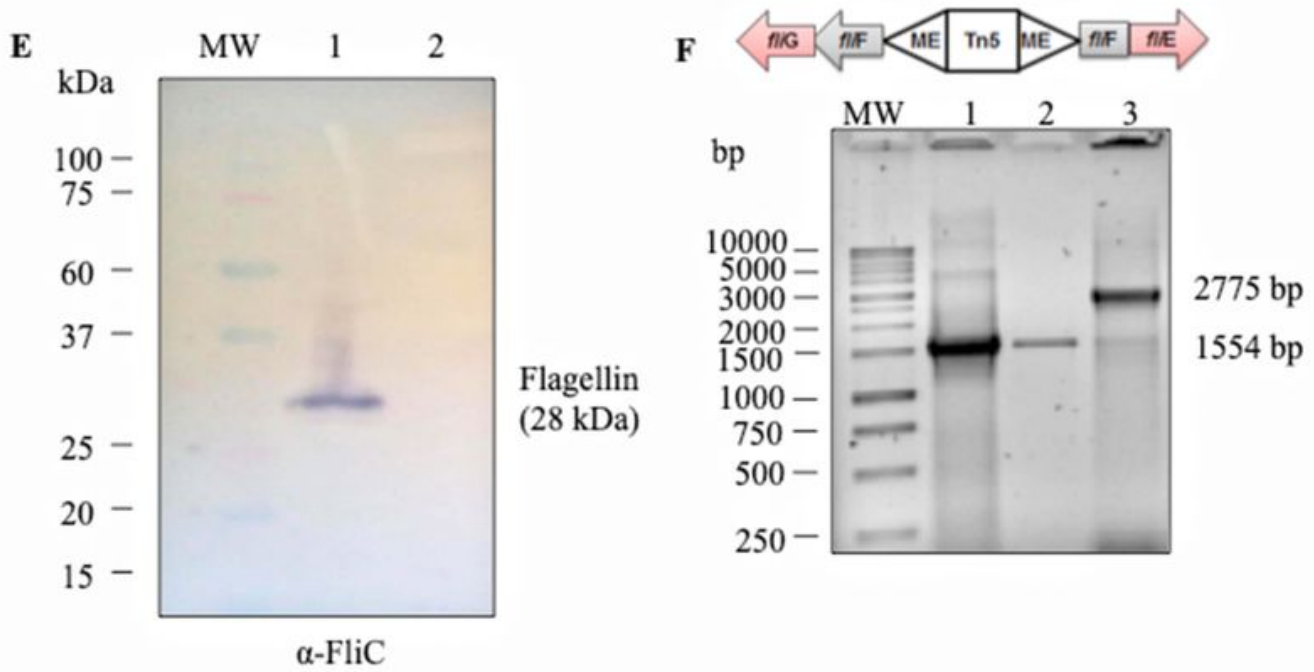

Flagellin

$(28 \mathrm{kDa})$

\section{Figure 1}

CS WT non-motile strain selection. (A) Visualization from the CS WT strain on LB $0.3 \%$ agar. (B) Visualization of the lack of motility in the CS fliF::Tn5 strain grown on LB $0.3 \%$ agar. (C) TEM micrograph showing the flagella of the CS WT strain after negative staining and visualized at a magnification of 10,000 x. (D) TEM micrograph showing the lack of flagella in the CS fliF::Tn5 strain after negative staining and visualization at a magnification of 15,700 x. (E) Depolymerization of purified flagella from 
the CS WT strain in 12\% SDS-PAGE gels (MW: molecular weight, $\mathrm{kDa}$ ) and a $28-\mathrm{kD}$ a protein corresponding to the structural flagellin (FliC) when reacted with rabbit anti-FliC antibodies. $(\mathrm{F})$ Identification of the Tn5 insertion site in the CS WT strain fliF gene when a $1 \%$ agarose gel was stained with ethidium bromide (MW: molecular weight, $1 \mathrm{~kb}$ ). Lane 1and 2: fliF gene of CS WT. Lane 3: fliF gene of the non-motile CS WT strain.

A
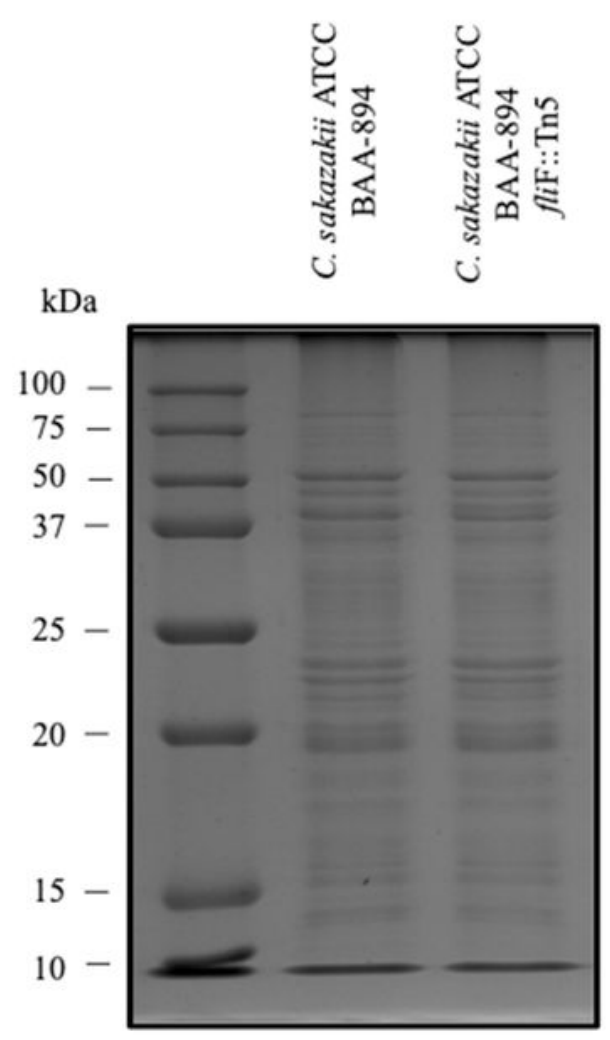

B

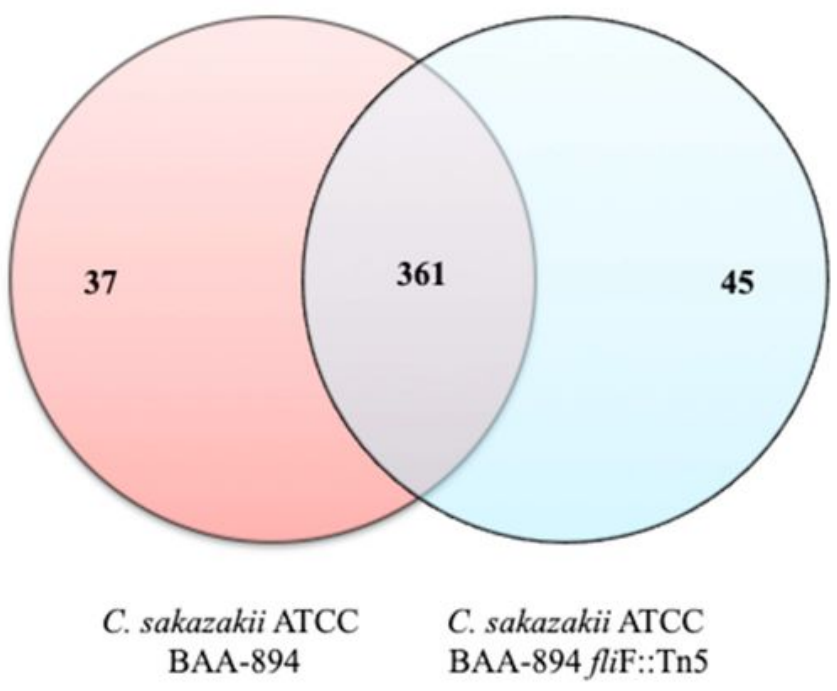

Figure 2 
Purified total membrane proteins from the CS WT and CS fliF::Tn5 strains. (A) 12\% SDS-PAGE analysis showing the profile of total membrane proteins after staining with Coomassie Brilliant Blue R-250. LMW: low molecular weight. (B) Venn diagram proteomes showing the total membrane proteins expressed by the CS WT and CS fliF::Tn5 strains.

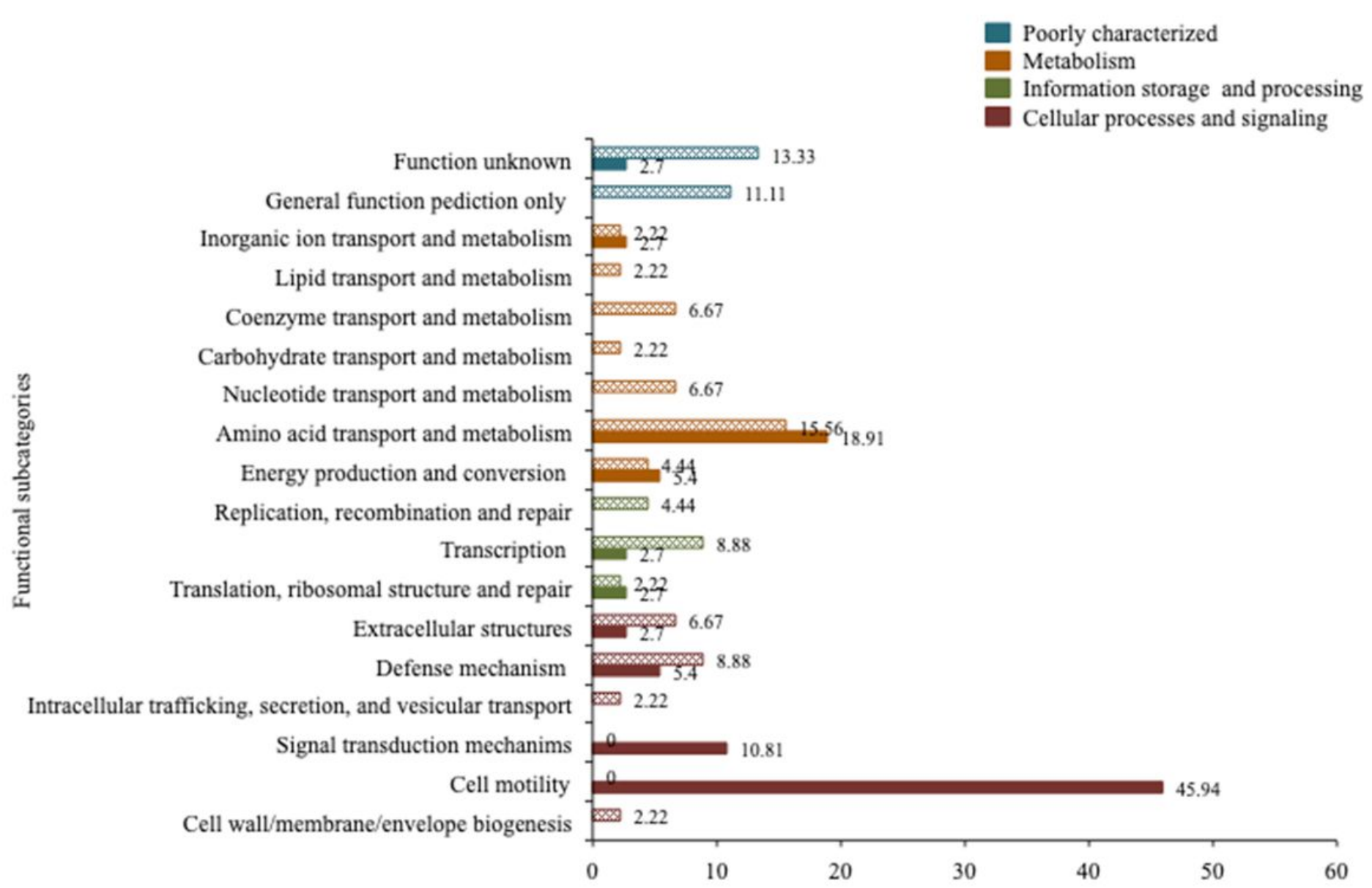

Percentaje (\%)

\section{Figure 3}

Proteomic profiles and functional categorization of proteins of the CS WT and CS fliF::Tn5 strains. The identified proteins from the proteomic analysis were classified into four categories: "cellular processes and signalling", "information storage and processing", "metabolism" and "poorly characterized". Solid bars represent the CS WT strain, and the bars with boxes represent the CS fliF::Tn5 strain. 


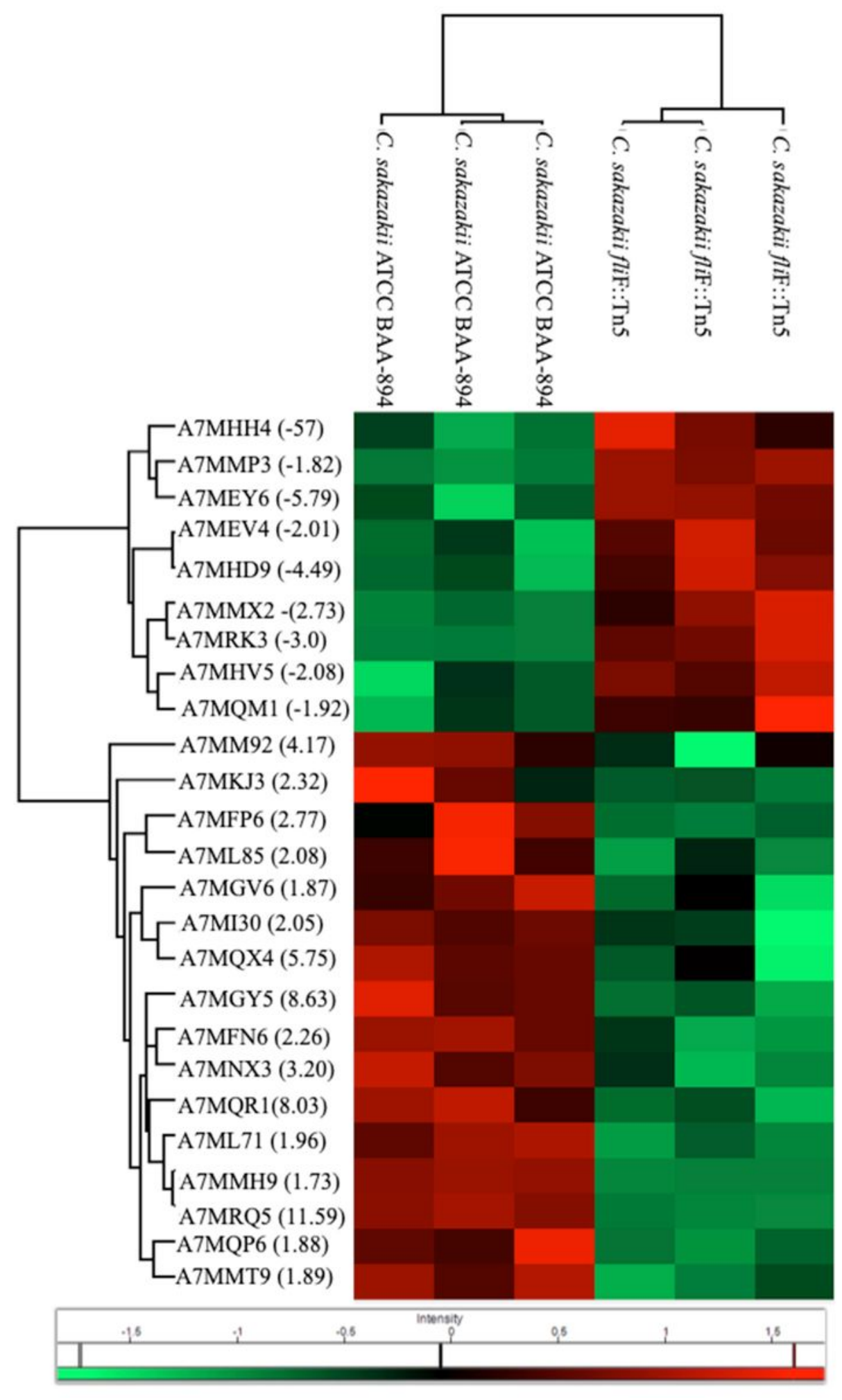

\section{Figure 4}

Heat map of the relative abundance of total membrane proteins expressed by the CS WT and CS fliF::Tn5 strains. The 25 proteins in the heat map for which the two sample Student's t-test showed statistical significance were analyzed with an unsupervised hierarchical clustering of the log 2 transformed and zscore normalized LFQi. Numbers in parenthesis represent the fold change dividing the average non- 
transformed LFQi detected in proteins of CS WT/CS fliF::Tn5 and negative numbers represent CS fliF::Tn5 /CS WT.

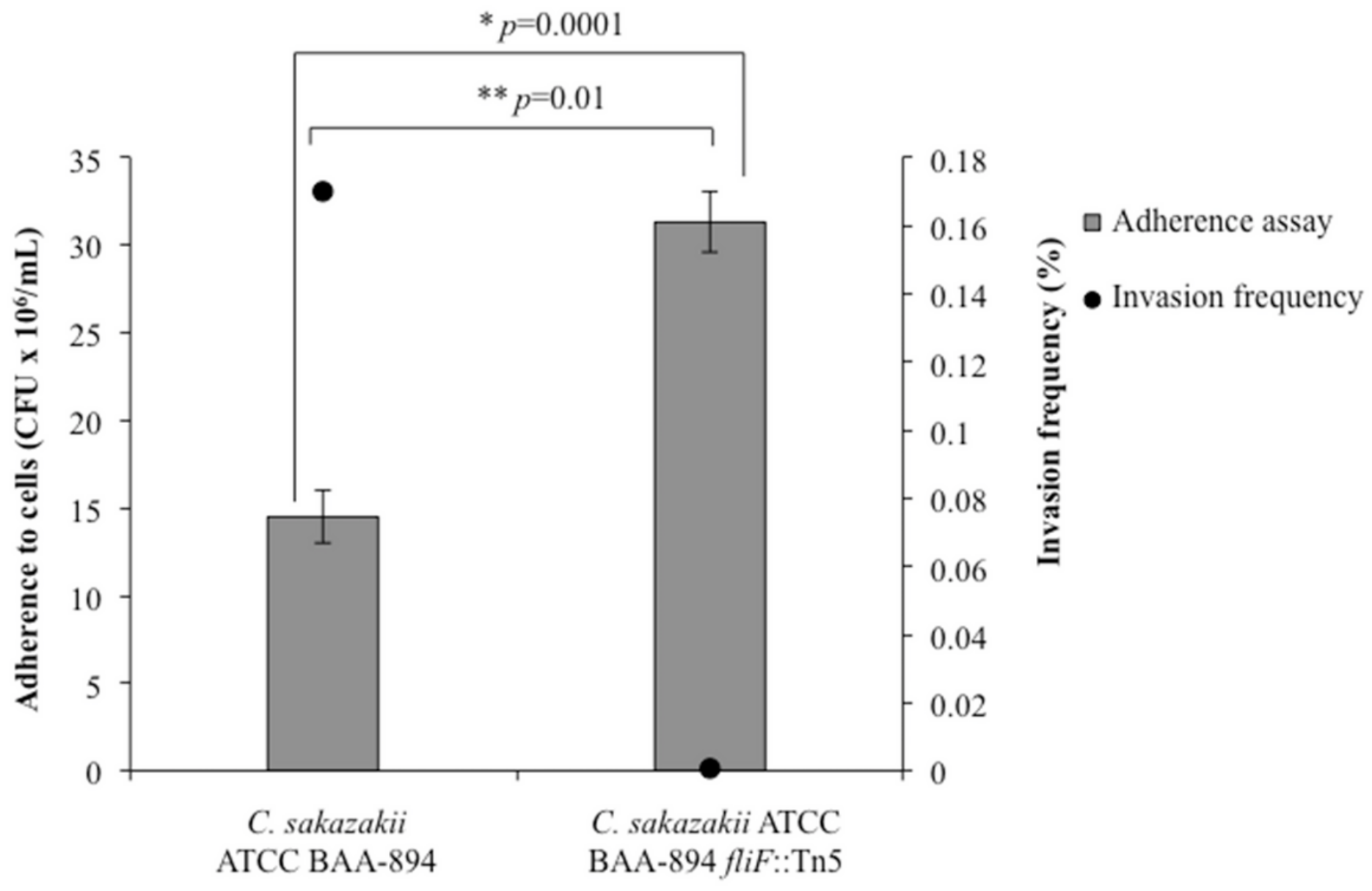

N1E-115 cells

* Adherence assay. ${ }^{* *}$ Invasion assay.

\section{Figure 5}

Influence of the flagella-producing CS WT strain in adherence and invasion. Quantitative analysis showed significant increases $(p=0.0001)$ in the adherence to N1E-115 cells of the CS fliF::Tn5 strain relative to the CS WT strain. The lack of flagella significantly reduces $(p=0.01)$ the invasion into N1E-115 cells.

\section{Supplementary Files}

This is a list of supplementary files associated with this preprint. Click to download. 
- SupplementaryMaterial1.xIsx

Page 25/25 